\title{
Térteremtő szavak
}

Gondolatok Ricardo Padrón The Spacious Word. Cartography, Literature, and Empire in Early Modern Spain címú múvéröl

\author{
Am Weihnachtstag des Jahres 1560 erreichten \\ wir die letzte Passhöhe des Andengebirges, und \\ sahen zum ersten mal in den gelobten Urwald \\ hinab. Am Morgen las ich die Messe, dann \\ stiegen wir in die Wolken hinab. \\ (Gaspar de Carvajal; Werner Herzog: Aguirre, \\ der Zorn Gottes, 1972)
}

Az utóbbi két évtized szociológiai, társadalom- és kultúratudományos diskurzusaiban úgy túnik, a korábbiakhoz képest kitüntetett figyelemben részesült a tér kategóriája. Bár egységes térparadigma nem lehetséges, a szociológia számára mégis termékeny lehet e téma vizsgálata, mert segítségével újratematizálhatók bizonyos alapkérdések. Ezek közül a térképészettörténeti fejlemények kapcsán a modernitás kialakulására vonatkozó kérdést fogom az alábbiakban kiemelni Ricardo Padrón múve alapján.

Több szerzó is felhívta rá a figyelmet, hogy a kora újkor és a modernitás sajátos térbeliséget teremtett például a fegyelmező intézményekben vagy az urbánus környezetben (Foucault 1990 [1975]; Lefebvre 1991 [1974]; de Certeau 2010 [1980]). Valószínúsíthetô, és részletesebb kifejtést igényelne, hogy a Foucault, Lefebvre és de Certeau által leírt térbeli konfigurációk számára a végtelenként, minőségileg homogénként, mérhetóként és az értelem fénye által megvilágítottként elgondolt tér képzete szolgált alapul. Emellett a modern központosított állam is e térkoncepció alapján szerveződött meg. A modern államok meghatározó jegye az adott terület feletti erőszakmonopólium, azaz létezik egy kormányzati, uralmi centrum, amely egy bizonyos területen kizárólagosan gyakorolja a hatalmat, vagy legalábbis legitim módo igényt tart rá. ${ }^{1}$ Jakab Dénes szerint az államterület elképzelésének gyökere a karteziánus filozófia. Descartes a testek (res extensa) releváns tulajdonságaként a kiterjedésüket nevezte meg. A három dimenzió alapján meghatározható térben foglalnak helyet az egymástól jól elkülönülő entitások, melyek kizárólagosan foglalják el a tér egy adott szegmensét (Jakab 2009: 164-165). A földfelszín ugyan nem háromdimenziós, nem is végtelen, de rokonság áll fenn a modern állam megszervezése és az újkorban létrejövố új térkoncepció között: az államok a földfelszín terébôl kihasított terület felett gyakorolják a hatalmat, méghozzá kizárólagosan, csakúgy, ahogyan a descartes-i elképzelés alapján sem lehet egy helyen két test.

1 E helyen eltekintek a hatalom és uralom weberi különbségtételétől. 
Látható, hogy a kérdés túlmutat önmagán, szociológiai jelentőséggel bír: amikor ennek a térfelfogásnak a geneziséról beszélünk, akkor egyúttal a modernitás kialakulásáról is beszélünk. Ezért létjogosult az a fajta szociológiai vizsgálati mód, amely a szociológia hagyományos szemléletmódjával (áttekintsszerúen: Schroer 2008) szemben nem csupán a társadalmilag létrehozott-módosított térrel foglalkozik, hanem különös figyelmet szentel a térre vonatkozó elgondolásoknak is. A geometriailag megszerkesztett, minőségileg homogén, mérhetô tér késôbbiekben oly fontossá váló koncepciójának születését rendszerint a késő reneszánsz és a barokk idôszakára szokták tenni. Viszonylag átfogó irodalma van annak, hogy hogyan járult hozzá a természettudományok mellett a filozófia és a festészetben a lineáris perspektíva e térreprezentáció kialakulásához (lásd Panofsky 1984 [1927]). Jóval kevésbé megvilágított téma azonban, hogy a középkor végén és az újkor hajnalán a térképészet is jelentôs hozzájárulást nyújtott eme átalakuláshoz.

E médium egyáltalán nem az a semleges vizuális reprezentáció, aminek gondolnánk. Saját térbeliséget hoz létre, amelynek csupán egyik speciális esete a modern, a hosszúsági és szélességi fokok által felrajzolt rácsozat által érzékeltetett tér. Vannak olyan elképzelések, amelyek rámutatnak, hogy a térképek többet jelentenek egyszerú vizualizálási eljárásoknál. Karl Schlögel szerint ,„a térképekben a kor tudása és elképzelései/képzetei manifesztálódnak. (...) Bennük mintegy magához tér a [korszak BV] világképe" (idézi: Schulte 2009: 5.). Vagyis Schlögel úgy véli, hogy az adott korszak alapvetố világlátása rányomja a bélyegét, kifejezódik a térképeken. Ezzel szemben érdemes lenne kölcsönhatásként felfogni ezt a viszonyt, hiszen nemcsak arról van szó, hogy a térképekről leolvashatók az adott korszakra jellemző térrel kapcsolatos elképzelések, világlátások, hanem ook maguk is alakítják e felfogásokat. ${ }^{2}$

Manapság a kultúra- és társadalomtudományok területére is begyứrüzött a térképek iránti érdeklődés. E vonulathoz kapcsolódik Ricardo Padrón The Spacious Word címú könyve is, melynek szerzője egy igen nagy és fontos feladatot túzött ki önmaga számára: rekonstruálni az európai civilizáció ama nagy kultúrtörténeti váltását, melynek során a tér középkori elgondolását (illetve elgondolásait) valami gyökeresen más váltotta fel az újkor folyamán. A mú kiindulópontja az az ismert tény, hogy a végtelen, minőségileg homogén, geometriailag elképzelt tér képzete nem, vagy csak csírájában létezett az európai középkorban, a maga teljességében az újkorban bontakozott ki, hogy aztán ez váljon a domináns, szinte egyeduralkodó térreprezentációvá.

Michel de Certeau (2010 [1980]): 117-127., 142-145.) klasszikus gondolatmenete kapcsán Padrón szembeállítja egymással az útvonalat a tér elgondolásának absztraktabb formájával (Padrón 2004: 60-61.). Elóbbi a cselekvő földközeli perspektívájához kötődik, az ô mozgását követi; egydimenziós, mivel az út mentén va-

2 Vö.: ,az olyan mediális diszpozitívok, mint a térképek esetében nem pusztán arról van szó, hogy ezek pusztán térbelivé tesznek már meglévő társadalmi viszonyokat, illetve leképeznek már létező területeket, hanem hozzá is járulnak mindkettőnek a konstituálódásához, [e] médiumok tehát nem csupán eszközök, hanem maguk is a világ létrehozásának bizonyos módozatát képviselik” (Döring 2008: 52.). 
ló haladás, a stációk egymásutánisága az egyedüli strukturáló elve, miközben figyelmen kívül hagyja azt, ami kívül esik az útvonalon. Ezzel szemben a „szabályos" modern térképek a táj egészére isteni magasságból letekintő megfigyelố nézőpontját tükrözik, az ő szemszögéből a tér egy négyzetrácsos koordinátarendszer által közrefogott felületté szerveződik. A középkor és az újkor/kora modernitás között nem az a fő eltérés, hogy az utóbbi korszakban az emberek már nem gondolkodnak útvonalakban, erről szó sincs, hiszen továbbra is elószeretettel használják ezt a sémát, amikor a térben (lakásban, városban, természetben) tájékozódnak, vagy térbeli elrendezéseket írnak le (de Certeau 2010 [1980]): 142-145.). A különbség inkább abban rejlik, hogy az újkorban a tér szisztematizált reprezentációnak területén a tér modern elgondolása jutott uralomra, háttérbe szorítva az összes többit, megfosztva ôket legitimitásuktól. Ezzel szemben a középkorban a térnek többféle reprezentációja létezett.

Padrón könyvébôl is kiderül az, ami a térképészettörténeti irodalomból is, hogy a középkori Európában többféle „térkép” létezett (bár mindegyikük meglehetősen ritka volt), amelyek egymástól elkülönült tradíciót képviseltek, és amelyek mindegyike egy speciális csoportot (pl. utazókat, navigátorokat, spirituális elmélyülésre vágyó személyeket) céloztak meg (Harvey 1991: 7.; vö. Padrón 2004: 53.). A középkorral kapcsolatban szokás beszélni mappa mundikról, lokális és regionális topográfiai térképekről, portolán térképekről és csillagászati térképekről. Ezek mindegyike valóban más és más célt szolgált, más és más közönséget szólított meg. Közös volt viszont bennük, hogy nem a modern térképek térbelisége volt jellemző rájuk: egyikük sem a hosszúsági és szélességi fokok által kifeszített, minőségileg homogén, végtelen teret képezte le méretarányos módon.

A mappa mundik - azaz világtérképek - szakrális szempontok alapján rendszerezték a teret: más értékkel látták el a különböző égtájakat (pl. a Kelet szent irány volt, míg a Nyugatot negatív előjellel látták el), ami alapján más volt a tájolásuk is (általában keleti), és emellett a világra és a történelemre vonatkozó vallásos ihletésû́ tudás egészét kívánták átfogó módon megjeleníteni (pl. gyakran konkrét helyet kap a térképen az Édenkert, vagy misztikus lények népesítik be a távoli, ismeretlen vidékeket). A csillagászati térképek, illetve az égi szférákat megjelenító ábrázolások esetében is nagy szerepet játszottak a szakrális megfontolások, emellett az általuk ábrázolt tér nem volt sem végtelen, sem minőségileg homogén. A lokális és regionális térképek esetében nagyobb változatosság figyelhető meg, de ezek sem méretarányosan ábrázolták a városokat, régiókat. E térképcsoport egyik alesetét képezték az útvonaltérképek, melyekre az útvonalak kapcsán kifejtett linearitás, egydimenziós jelleg volt jellemzó - annak ellenére, hogy kétdimenziós felületen jelenítettek meg útvonalakat, mivel a hányaveti, gyakran csak tessék-lássék módon megrajzolt régió csupán háttér gyanánt szolgált. A térkép maga a cselekvő földfelszínen végrehajtott mozgásait, az ő perspektíváját vette alapul. A tengeri navigáció eszközeiként szolgáló portolán térképek sokkal pontosabbak voltak a többinél. A Mediterráneumot vagy Európa egészét ábrázolták; jellemzően a partvonalakra koncentráltak, ezeket méretarányosan jelenítették meg (a belföldet pedig elhanyagolták), feltüntetve a part mentén található helységeket. Ugyanakkor nem a hosszúsági és szélességi 
fokok, hanem a szélrózsa által jelzett szélirányok osztották kisebb egységekre ezt a teret. A portolán térképek tehát annak ellenére, hogy a modern térképészet szemszögéből akkurátusabbak voltak, továbbra is kötődtek az utazók által befutott útvonalakhoz (mind eredetükben, hiszen nem csillagászati megfigyelések, hanem a part mentén tett utazások alapján rajzolták meg ôket, mind felhasználásukban, hiszen lehetséges útvonalakat lehetett felrajzolni e térképeket alapul véve). Padrón ez utóbbi kettő típust vizsgálta behatóan, bemutatva azt a folyamatot, amelynek során a 16. századtól kezdve e térképformákat fokozatosan háttérbe szorította a modern térkép (Padrón 2004: 53-84; ;ásd még: Padrón 2002; Harvey 1991).

Padrón a térképek szokásosnál tágabb definíciójával él, mely alapján a terek diszkurzív leírásai is részét képezik a fogalomnak. ${ }^{3}$ Könyvének gerincét ennek megfelelően azok a szellemes és mélyreható elemzések teszik ki, amelyekben a 16. századi spanyol történészek, írók, hódítók, földrajztudósok, katonák vagy költôk írásait veszi górcső alá a térbeliség megjelenési módjának szempontjából. E múvek az átmenet korszakának lenyomatát viselik magukon, amelyben fokozatosan, megtorpanásokkal, de szépen lassan eltolódás következett be a térrôl való gondolkodásban. A szemügyre vett írások is (egy kivételtôl eltekintve) mind átmeneti formákat képviselnek, hibrideket, amelyekben egyszerre van jelen az útvonalszerú, egydimenziós és másfelől a modern, felületszerû, az isteni magasság szemszögéhez kötődő térbeliség. ${ }^{4}$

Hernán Cortés V. Károlyhoz írt második, a mai Mexikó belső területén végrehajtott hadjáratáról szóló levele (1520) az egyetlen, amelyik még kizárólagosan a középkori (vagy még régebbi) térfelfogáshoz kötődik. Cortés nem a mai szemmel normálisnak tûnő módon írja le Új Spanyolországot, mivel a maga egészében, egy magaslati perspektívát felvéve sohasem beszél a területről. Nem tér ki Új Spanyolország formájára, hogy milyen folyói vannak, illetve milyen határok veszik körül (Padrón 2004: 98.). Ehelyett a szöveg egy utazást ír le Veracruzból Tenochtitlánba, az azték birodalom akkori foovárosába - Új Spanyolország tehát egy útvonal mentén jelenik meg. A kifejtés logikája - mivel soha nem a mindent látó isteni szem magasságából szemlélve, a hangsúlyt soha nem a vizuális aspektusra helyezve kívánja leírni a mai Mexikót - nagyon is közel áll a középkori útvonaltérképekéhez.

Míg Cortés megmarad az útvonalszerú térfelfogásnál, addig a 16. századi spanyol irodalom klasszikus múvében, az Araukánok könyvében a Padrón által elemzett többi múben is megjelenő vegyes vagy átmeneti térbeliség érhetô tetten. Ebben az epikus költeményben a szerzô, Alonso de Ercilla egyes szám elsố személyben számol be a spanyoloknak a chilei araukánok ellen folytatott háborújáról. 5 E monumentális alkotásnak számos olyan passzusa van Padrón szerint, amelyek az újfajta térképek újfajta térbeliségére épülnek, ,amennyiben egy parancsoló magasságból

3 Terjedelmi korlátok miatt nincs módom kitérni arra a kérdésre, hogy miképp lehet meghatározni a térképeket, és mennyire jogosult Padrón lépése.

4 Terjedelmi korlátok miatt két múre térek ki csupán.

5 A mú magyarul is megjelent: Araukánok könyve (3 kötet, Budapest: Eötvös, 2006, 2007, 2008). 
adnak átfogó képet a területekról, és amennyiben azt sugallják, hogy az egyes pontok egymás mellett léteznek e felületen" (Padrón 2004: 225.). A vizualitás előtérbe kerülése nyilvánul meg Ercilla pontos, az olvasót a terület elképzelésére ösztönző leírásaiban, Chile pontos kartográfiai ábrázolásában, valamint a költemény egyik kulcsmomentumában, az ún. mappa mundi jelenetben. Ez utóbbiban Fitón, a chilei varázsló megmutatja Ercillának, a mú főhősének hatalmas varázsgömbjét, amely a világ különböző részeit mutatja meg neki madártávlatból (uo. 206-207.). Másrészrôl a linearitás is jelentős szerepet kap Ercillánál, méghozzá abban, hogy a harci cselekmények északi-déli mozgások sorozataként jelennek meg: a spanyol seregnek a továbbjutás érdekében mindig bizonyos hegyszorosokon kell keresztüljutniuk, mindig brutális harcok árán tudnak csak továbblépni (ha egyáltalán, hiszen gyakoriak a vereségek is). A Chile területén végrehajtott ,vertikális” mozgások ábrázolása nem csupán a lineáris térfelfogás kontextusában érdekesek. Padrón értelmezésében a szerző alapvető beállítódását is tükrözik, mivel a hódítók által Chilén gyakorolt nemi erőszak allegorikus megjelenítései, míg a szorosok a nőiség és az ellenálló Chile szimbólumai (uo. 195-196.).

Az ismertetett elemzésekből is kiviláglik, hogy Padrón könyve igen szubtilis és eredeti módon értelmezi a spanyol kultúrkör e klasszikus alkotásait. Emellett segít abban is, hogy differenciáltabban közelíthessünk meg egy, a nyugati kultúrkör fejlődésével kapcsolatos, kiemelten fontos kérdést. Az, amit e kultúrkör „racionalizálódásaként" szokás emlegetni, általában Janus-arcú folyamatként jelenik meg az e kérdést vizsgálók számára, mivel az ismeretek gyarapodása, rendszerezése, a világ feletti nagyobb kontroll e szerzők szemében együtt jár az instrumentális logika uralomra jutásával, a természet és az embertársak objektiválásával, a kiaknázó beállítódás dominánssá válásával. E sötét diagnózis van jelen hol implicit, hol explicit módon Weber racionalizációelméletében és teljesen nyíltan a frankfurti iskola első generációjának múveiben, illetve Habermas rendszerevolúcióval kapcsolatos gondolataiban. A modernitás kialakulását egy kétarcú racionalizálódási folyamatként rekonstruáló gondolati séma igen befolyásos a társadalomtudományok körében, így az sem meglepő, ha a térfelfogások átalakulását is többen e szemüvegen keresztül szeretnék értelmezni.

Az a nagy átalakulási folyamat, amelynek során a térreprezentációk középkori pluralitását a kartográfia területén a modern térkép uralma váltotta fel, e gondolati séma alapján a „racionalizálódás” részeként jelenik meg. Ezt a „racionalizálódást” aztán ugyanazzal a kettős jelleggel látják el. A modern térképek egyrészt minden korábbinál pontosabban ábrázolják a földfelszínt, „racionalizálják” a teret, megfosztják nemcsak a szerkesztésbeli pontatlanságoktól, de mindenféle misztikus-mágikus tartalomtól is. Másrészt az isteni magasságból ily módon szemügyre vett és az e mindenható és uralkodni vágyó szem számára felkínált terület feletti szisztematikus kontrollt is lehetôvé teszik. Woodward e témában írt tanulmányának zárógondolata jól szemlélteti ezt az elképzelést, szerinte ,a föld egészének e [racionalizált - B. V.] képe hozzájárult azon eszme kialakulásához, miszerint a világ véges és lehetséges szisztematikus uralmat gyakorolni felette, továbbá hatékony keretrendszert szolgáltatott a politikai expanzió és kontroll megvalósítása számára" 
(Woodward 1991: 87.). A „racionalizált” térrel rendelkező térkép így a kizsákmányolás, a felügyeletgyakorlás, a területi igazgatás vagy expanzió stb. ágensévé: előmozdítójává és közvetítőjévé válik.

Padrón múve alaposan belerondít ebbe a jól kigondolt, ám a dolog lényegét tekintve mégiscsak meglehetősen egyszerú képletbe. A térbeliség cortési kezelésének rekonstrukciója épp arra világít rá, hogy az útvonalszerú térfelfogás is éppúgy szolgálatába állítható különféle kizsákmányoló, hódító projekteknek. Az instrumentális logika ezek alapján nem kizárólag a modern „racionális” térképzethez kötődik, a középkort nem érdemes e tekintetben romantikus elvágyódási hajlamok alapján pozitívabban megítélni. Cortés nem kevésbé volt kegyetlen, expedícióját nem kisebb mértékben indította a megszerezhető dicsőség, hatalom és gazdagság reményében, mint azok a későbbi hódítók vagy kereskedők, akik már a modern térbeliség talaján álltak. A középkori térbeliség tehát igen jól szolgálta a gyarmatosítói tevékenységet annak kezdeti

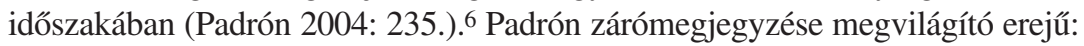

(...) érdemes lenne hosszasan elgondolkoznunk azon, hogy milyen politikai értékkel látunk el bármit a saját kultúránkban, amely a modernitás előttről származik, és manapság már csak e modernitás peremén létezik (...) [h]ajlamosak vagyunk a modernitás eme alternatíváit inherensen felszabadító jellegúként elgondolni, mégis: érdemes lenne emlékeztetni önmagunkat arra, hogy ezek is lehetnek a hatalom eszközei. A derékszögú négyzetrács nem az egyetlen olyan eszköz, amellyel feltérképezhető/eltervezhető (map) egy birodalom. (2004: 238.).

Padrón ugyan teljesen nem veti el a „hagyományos” vélekedést, de láttatni kívánja, hogy a gyarmatosítás első időszakára nem volt igaz. Összességében úgy tûnik tehát, hogy azt az instrumentális logikát, amely a térképek kapcsán a gyarmati kizsákmányolás, az igazgatás és a kereskedelem hatékonysága kapcsán jelenhet meg, nem az új térbeliség hozta létre. Az egydimenziós térfelfogás nagyon mélyen gyökerezett ebben a kultúrában. Így nem pusztán arról van szó, hogy a hódítások elsô szakaszában, amikor ismeretlen területre kerülnek az emberek, akkor szükségszerúen e séma alapján orientálódnak, míg a hatalom szisztematikus kiépítése folyamán vagy után, annak fenntartása érdekében, kialakul a modern térreprezentáció. E célokat a középkori térfelfogás is képes volt szolgálni. ${ }^{7}$

6 Erre mutatott rá ösztönösen Werner Herzog az Aguirre, Isten haragja (Aguirre, der Zorn Gottes) címú filmjében, melyben a konkvisztádor, Aguirre cseppet sem szimpatikus figura: hódítani, rabolni, zsákmányolni és alávetni akar. A film érdekessége, hogy a cselekmény tulajdonképpen nem más, mint egy útvonal (mely kudarcban végződik), és érzékelhető, hogy a szereplők is ily módon gondolkodnak a térről. Mindezt a Popol Vuh (találó névválasztás!) atmoszferikus zenéje festi alá, mely tökéletesen érzékelteti az ismeretlen terek misztériumát.

7 Ez világossá válik Padrón leírásaiból is. Amikor a 16. század második felében a spanyol királyi udvar kozmográfiai szervezetének megbízásából felszólították a Közép-Amerikai gyarmati tisztviselőket (tehát a már berendezkedett, konszolidálódott hatalom képviselőit), hogy rajzolják meg a rájuk bízott terület térképét, akkor meglehetôsen nagy arányban kaptak útvonaltérképeket a kozmográfusok (vö. Padrón 2002: 30-31., 39-42., 2004: 75-81.). 
A Spacious Word azért is élvezetes olvasmány, mert mindezek mellett arra késztet, hogy átgondoljuk néhány problémamentesnek vélt fogalmunkat. Ezek közé tartozik a „racionalizáció” is. Padrón könyve nyilvánvalóvá teszi, de a szakirodalom kritikai olvasása is arra a következtetésre sarkall, hogy a „racionalizáció” fogalma meglehetősen problematikus. Mégis mit jelent az, hogy racionális, hogy valami racionálisabb, mint más? Mi a racionalitás meghatározó kritériuma? És mi az, hogy racionalizáció? Olyan kérdések ezek, amelyek gyakran reflektálatlanok maradnak, noha lényegesek lennének. A probléma ott kezdődik, hogy nincs a racionalitásnak abszolút mércéje. Már Weber is arról írt, hogy ,az életet a legkülönbözőbb irányokban lehet »racionalizálni«" (Weber 1982 [1904-1905]: 86.). Amikor a térképészettörténeti irodalomban racionalizációról írnak, akkor rendszerint a geometriai elvek uralomra jutását értik ezalatt: a tér mérhetőségének gondolatát, azt, hogy a természetet geometriailag arányosan, egy hosszúsági és szélességi fokok alapján felépülő rácsozat felhasználásával kívánták reprezentálni, minek következtében az ily módon felépülő ,absztrakt” tér minőségileg homogénné vált (Woodward 1991: 84., 87.). Az átmatematizáltság mint a racionalitás kritériuma azonban nem a dolgok természetéből, hanem csak a tudományos közösség áthagyományozott meggyőződéseiból fakad, vagyis nem szükségszerú. Padrón maga jegyzi meg, hogy a mappa mundik is „racionalizálták” a teret, de nem matematikai alapon, hanem a középkori kereszténység kulturális prioritásai alapján (2004: 35.). Racionalizálni tehát sokféleképpen lehet, akár oly módon is, hogy a racionalizálás fogalma homlokegyenest ellentmond annak, amit a térképészettörténet múvelői általában értenek alatta.

Padrón e tekintetben viszonylag következetes: racionalizálásról a legtöbbször úgy ír, hogy az derül ki, ez többféle értelemben lehetséges. ${ }^{8}$ Az ilyen megengedő szóhasználat ugyan egy fokkal jobb, mint a kifejezés reflektálatlan alkalmazása, de problémát is okozhat, ugyanis a racionalizáció fogalmának teljes kiürülését eredményezheti. Túlzottan sokféle, egymással ellentétes szempontból lehet racionalizálni, így talán megfelelőbb volna, ha a tér ilyen vagy olyan racionalizása helyett a tér rendszerezéséről beszélnénk. Minden jel arra utal tehát, hogy a „racionalizáció” elgondolása nem nyújt megfelelő fogalmi keretet, és valahogy másképp kellene rekonstruálni az átalakulást. Olyan fogalmiságra lenne szükség, amely képes számot adni arról, hogy a terek egymástól fundamentálisan különböző módon tudnak felépülni; melynek segítségével minden különösebb gond nélkül megragadhatóvá válna a terek konstituálódásának eme öntörvényú logikája, hogy rá lehessen mutatni a tér megszerveződési módjainak sajátosságaira. És kifejezetten előnyös lenne, ha mindezt úgy tudná e fogalmiság nyújtani, hogy közben az egyik térbeliséget nem értékeli magasabbra vagy alacsonyabbra, mint a másikat, hogy a fundamentális különbözőség elve teljesen érvényesülni tudjon.

8 Egy helyen arról ír, hogy a ptolemaioszi ihletésú térkép az euklideszi geometria alapján racionalizálja a teret (Padrón 2004: 32.), egy másik - már említett - kontextusban pedig a mappa mundik kapcsán említi, hogy ezek a közékori kereszténység kulturális prioritásai nyomán racionalizálták a kartográfiai teret (uo. 35.). Mindkettő a számos racinoalizálási lehetőség egyikeként jelenik meg e helyeken. 
Ezt a döntő lépést Padrón nem tette meg, nem szakadt el teljesen a racionalizáció sémájától. Persze ő sem rangsorolja a különbözô tereket, de olyan fogalmisággal dolgozik, amely eredetileg értékelő volt, és a megoldása inkább az inherens tendencia ellenében végrehajtott toldozgatás-foldozgatás benyomását kelti. Bizonyára több alternatíva állna rendelkezésre egy megfelelő fogalmi keret kialakítására, ám e helyütt csak egy lehetôséget említenék, amelyik viszont különösen kézenfekvőnek tűnik. Mint az ismeretes, Ernst Cassirer szerint léteznek különböző szimbolikus formák, amelyek ,,a szabad alkotás princípiuma[iként]”, önmagukban ,zárt és egységes alaptevékenység[ekként]” (1993 [1923]: 206.) mind sajátos és egymásra visszavezethetetlen módon formálják meg az észlelhető valóságot. Valamennyi szimbolikus forma (a nyelv mint egész, a mítosz mint egész, a múvészet mint egész vagy a tudományos megismerés mint egész) kibontakoztatja a maga saját, mással össze nem hasonlítható logikáját (vö. Cassirer 1993 [1923]: 206.). A térre vonatkoztatva mindez azt jelenti, hogy a tér nem valami ténylegesen létező dolog, hanem mindig a szimbolikus megformálás múveletének eredménye:

(...) nincs általános, teljességgel szilárdan álló térszemlélet, hanem a tér abban az értelmi rendben nyeri el meghatározott tartalmát és sajátos illeszkedését, melyben formálódik. A tér ,formája” aszerint változik, hogy mitikus-, esztétikai- vagy teoretikus térként gondoljuk-e el, és ez a változás nem pusztán az egyes és alárendelt vonásokat érinti, hanem egészként vonatkozik rá és elvi struktúrájára. A tér nem rendelkezik egy teljességgel, egyszer s mindenkorra szilárdan adott struktúrával; e struktúrát csak azon általános értelmi összefüggés által nyeri el, melyben felépülése végbemegy. (Cassirer 2000 [1931]).

Amennyiben tehát a tér eltérô módon konstituálódhat, úgy e különböző terek szolgálhatnak alapul a térképek megrajzolásának. És talán nem is lenne olyan nehéz rámutatni ezen összefüggésekre. Így azt mondhatnánk, hogy a mitikus gondolkodás szimbolikus formája szervezi meg a mappa mundik terét - minthogy a különböző égtájaknak és helyeknek eltérő mitikus minőséget tulajdonít. ${ }^{9}$ Az útvonaltérképek térbeliségét a nyelv szimbolikus formájával lehetne összekapcsolni, amennyiben a nyelvfejlődés korábbi szakaszaiban megjelenő tulajdonság, ti. a cselekvő nézőpontjához kötődés az alapja e térképfajtának is. ${ }^{10} \mathrm{~A}$ modern térképek tere pedig a tiszta megismerés teoretikus terére épülne, mivel mindkettő szigorú geometriai elveken nyugszik. ${ }^{11}$ Kétségtelenül vannak olyan kérdések, amelyek nem tisztázhatók első

9 A tér és a mítosz szimbolikus formájának kapcsolatához lásd: Cassirer (2000 [1931], 2002 [1925]: 98-123.). A mitikus gondolkodáshoz átfogóan és magyarul lásd még Cassirer (1969 [1922]). A helyzet természetesen nem ilyen egyértelmú, hiszen a mitikus gondolkodás számára a szó vagy a vizuális reprezentáció azonos magával a dologgal. Ez pedig nem valószínú, hogy igaz, több jel arra utal, a középkorban tudatában voltak annak, hogy a térképek reprezentációk. Így a mappa mundik leginkább a mítosszal ambivalens viszonyban lévő vallás szimbolikus formájához kötődnek.

10 A tér és a nyelv szimbolikus formájának kapcsolatához lásd: Cassirer (2001 [1923]: 147-168.).

11 A teoretikus térhez lásd Cassirer (2002 [1929]: 159-182.). 
ránézésre (Mely szimbolikus formához kapcsolódnak a portolán térképek és azok a regionális vagy lokális térképek, amelyek nem útvonalszerúek? Megengedi-e a cassireri terminológia a vegyes típusokat?), de az mindenestre látszik, hogy a tér eme cassireriánus felfogása ${ }^{12}$ igen jól ki tudja küszöbölni azokat a fogalmi problémákat, amelyekkel Padrón is küszködött. A térbeliség tekintetében megfigyelhető epochális átalakulás ezek alapján a szimbolikus formák átrendeződéseként: egyesek háttérbe szorulásaként, míg mások előtérbe lépéseként lenne megragadható. Mindez természetesen jövőbeli kutatásoknak lehetne a tárgya, melyek keretében talán jobban utána tudnánk járni annak a kérdésnek, hogy a térfelfogások átalakulása mennyiben jelez társadalmi változásokat.

\section{Hivatkozott irodalom}

CASSIRER, ERnst (1969 [1922]): A mitikus gondolkodás fogalmi szerkezete. Világosság 10 (10), 10-13. (Melléklet az 1969. októberi számhoz.)

CASSIRER, ERnST (1993 [1923]): A szimbolikus forma fogalma a szellemtudományok felépítésében. Filozófiai Figyelö 14, 203-225.

CASSIRER, ERnST (2000 [1931]): Mitikus, esztétikai és teoretikus tér. Vulgo 2 (1-2), 237-246. Internet: http://www.c3.hu/scripta/vulgo/2/1-2/cassir.htm

CAssirer, ERnst (2001 [1923]): Philosophie der symbolischen Formen. Erster Teil: Die Sprache, Gesammelte Werke. Hamburg, Meiner.

CASSIRER, ERnst (2002 [1925]): Philosophie der symbolischen Formen. Zweiter Teil: Das mythische Denken. Hamburg, Meiner.

CASSIRER, ERnST (2002 [1929]): Philosophie der symbolischen Formen. Dritter Teil: Phänomenologie der Erkenntnis. Hamburg, Meiner.

de Certeau, Michel (2010 [1980]): A mindennapok leleménye 1. A cselekvés müvészete. Budapest, Kijárat.

DÖRING, JÖRG (2008): Die Karte als Operations- und Imaginationsmatrix. Zur Geschichte eines Raummediums. In Jörg Döring és Tristan Thielmann (szerk.): Spatial Turn. Das Raumparadigma in den Kultur- und Sozialwissenschaften. Bielefeld, Transcript, 49-69.

Ferrari, MAssimo (1992): Cassirer und der Raum. Sechs Varianten über ein Thema. Internationale Zeitschrift für Philosophie 2 (1), 167-188.

Foucault, Michel (1990 [1975]): Felügyelet és büntetés. Budapest, Gondolat.

Harvey, P. D. A. (1991): Medieval Maps. London, The British Library.

JAKAB DÉNEs BARna (2009): Területiség és deterritorializáció. A terület mint a társadalomelmélet vezérfonala. Replika (66), 163-176.

Lefebvre, Henri (1991 [1974]): The Production of Space. Oxford, Basil Blackwell.

12 Cassirer térrel kapcsolatos gondolatairól összefoglalóan, hat szerzővel való szembeállítás során kifejtve lásd Ferrari (1992). E helyen szeretném megköszönni Weiss Jánosnak, hogy országhatárokat átszelve beszerezte nekem ezt a tanulmányt. 
PANOFSKY, ERWIN (1984 [1927]): A perspektíva mint „,szimbolikus forma”. In uő: A jelentés a vizuális múvészetekben. Budapest, Gondolat, 170-248.

PAdRón, RicARdo (2002): Mapping Plus Ultra. Cartography, Space, and Hispanic Modernity. Representations 79 (1), 28-60.

PADRÓN, RicARDO (2004): The Spacious Word. Cartography, Literature and Empire in Early Modern Spain. Chicago, London, University Of Chicago Press.

Schroer, Markus (2008): Soziologie. In Stephan Günzel (szerk.): Raumwissenschaften. Frankfurt am Main, Suhrkamp, 354-369.

SCHUlte, BENEDIKT (2009): Karte als symbolische Form. Kartographische Repräsentationen des Raums und ihre Transformation durch technische Bilder. Eine vergleichende Analyse der Ebstorfer Weltkarte ung Google Earth (seit 2005). Szakdolgozat, Stiftung Universität Hildesheim, Grin.

WEBER, MAX (1982 [1904-1905]): A protestáns etika és a kapitalizmus szelleme. Vallásszociológiai írások. Budapest, Gondolat.

WoODWARD, DAVID (1991): Maps and the Rationalization of Geographic Space. In Jay A. Levenson (szerk.): Art in the Age of Exploitation. New Haven, Yale University Press, 83-87. 